\title{
Metalloproteinase Inhibitor 3
}

National Cancer Institute

\section{Source}

National Cancer Institute. Metalloproteinase Inhibitor 3. NCI Thesaurus. Code C17681.

Metalloproteinase inhibitor $3(221 \mathrm{aa}, \sim 24 \mathrm{kDa})$ is encoded by the human TIMP3 gene.

This protein is involved in metalloproteinase inhibition. 